\title{
COMPARATIVE THERAPEUTIC VALUE OF MASSAGE WITH "ADRENALINE CREAM" AND WITH ANOTHER CREAM IN CONDITIONS ASSOCIATED WITH DEEP PAIN
}

The therapeutic trial described below was designed at the request of the research subcommittee of the Empire Rheumatism Council to evaluate the specific efficiency of a proprietary product, widely advertised in the lay press as a cure for rheumatism, etc., and claimed by Moss (1949) to be of very great value in fibrositis.

The specific question asked was whether there was any difference between "Adrenaline Cream" and a similar cream not containing adrenaline, such as Howell (1950) had noted. The latter author obtained relief " within a few minutes " which " lasted for several hours at least". In 83 out of ninety patients with chronic fibrositis usually secondary to rheumatoid arthritis or osteo-arthritis, the inunction of adrenaline cream by deep massage relieved the pain for from 10 minutes to 5 days. "The usual duration of freedom from pain was 12 hours." Similar results were obtained with other medicated creams containing ephedrine or belladonna, but " a blank control cream gave only 2 or 3 hours relief in most of the twenty patients ",

\section{Procedure}

The experiment was carried out at the following ten rheumatism centres in England and Scotland: Royal Infirmary, Aberdeen (Dr. Logie Bain), University College Hospital, London (Dr. H. A. Burt), West London Hospital (Dr. W. S. C. Copeman), Northern General Hospital, Edinburgh (Dr. J. J. R. Duthie), Royal Free Hospital, London (Dr. E. Fletcher), Middlesex Hospital, London (Dr. F. D. Howitt), Royal Infirmary, Manchester (Dr. J. H. Kellgren), Royal National Hospital for Rheumatic Diseases, Bath (Dr. G. D. Kersley), and the Canadian Red Cross Memorial Hospital, Taplow, and British Postgraduate Medical School, London (Dr. E. G. L. Bywaters). Dr. E. Lewis-Faning gave advice and made useful suggestions regarding the planning of the trial and its statistical analysis.

Material.- "Adrenaline Cream" was used as supplied by the makers (Messrs. Howard Lloyd of Leicester). Comparison was made with the effects of a control cream (similar but not containing adrenaline), as used by Howell (1950):

$\begin{array}{llll}\text { Emulsifying wax } & \ldots & 20 \text { parts } \\ \text { Wool fat } & . . & \ldots & 10 \text { parts } \\ \text { Chlorocresol } & & . . & 0.05 \text { parts } \\ \text { Water } & . & . . & 100 \text { parts }\end{array}$

The cost of these materials is $1 d$. per oz.; the cost of the " adrenaline cream" is $3 s .9 d$. for a 2-oz. tin, which includes the cost of mixing, packaging, marketing, etc.

Cases.-Patients were selected with bilateral back pain or pain in two non-symmetrical positions in the body due to " fibrositis" (i.e. deep pain referred to muscle): the presence of degenerative joint disease or rheumatoid arthritis did not exclude the case. 
Method.-The two creams were labelled by the pharmacist " $A$ " and " B ", so that although slight differences were noted in the two creams by the investigators, they did not know beforehand which was which. Some observers noted that the adrenaline cream darkened slightly on exposure, or that one of the creams rubbed in slightly differently. All the massage in each centre was done by the same person.

The two creams were each massaged into one of the two sites for five minutes, and the effects assessed before treatment, and $5 \mathrm{~min}$., $30 \mathrm{~min}$., and one week after starting treatment. At the second attendance (one week from the first inunction) the sites of inunction of the creams were reversed and the same procedure carried out.

Evaluation of Effects. - Subjective assessment of pain was made by enquiring how bad the pain was before and at each of the three intervals afterwards. It was graded 0 , 1, 2 (none, mild, severe). Objective tenderness was tested by manual pressure, before and at each of the three intervals afterwards (graded 0,1 , and 2 as above). The retrospective duration of relief, if any, was enquired into at the two weekly return visits.

\section{Results}

It will be seen that improvement, partial (from Grade 2 to Grade 1) or complete (from Grade 1 or 2 to 0 ), occurred in one quarter of the trials (Table I, opposite), irrespective of whether comparison was made

(a) between the two creams,

(b) between the two sites,

(c) between the subjective and the objective assessment,

(d) between the first trial and the replication,

(e) between the 5-minute and the 30-minute assessment (Table II below). The greatest difference (Table II) was between the 5-minute and the 30-minute assessment, but this was not large and should be ascribed to the psychological response on the part of the patient to a repetition of the pain enquiry.

TABLE II

NUMBER IMPROVED OUT OF POSSIBLE IMPROVEMENTS

\begin{tabular}{|c|c|c|c|c|c|c|c|c|c|}
\hline $\begin{array}{l}\text { First } \\
\text { Trial }\end{array}$ & $\begin{array}{c}\text { Second } \\
\text { Trial }\end{array}$ & $\begin{array}{c}\text { Sub- } \\
\text { jective }\end{array}$ & $\begin{array}{c}\text { Ob- } \\
\text { jective }\end{array}$ & $\begin{array}{l}\text { Adrena- } \\
\text { line }\end{array}$ & Control & $5 \mathrm{~min}$. & $30 \mathrm{~min}$. & $\begin{array}{l}\text { One } \\
\text { Side }\end{array}$ & $\begin{array}{l}\text { Other } \\
\text { Side }\end{array}$ \\
\hline $4 / 36$ & $12 / 31$ & $4 / 36$ & $9 / 38$ & $4 / 36$ & $7 / 38$ & $4 / 36$ & $12 / 36$ & $4 / 36$ & $12 / 31$ \\
\hline $9 / 38$ & $6 / 36$ & $12 / 31$ & $6 / 36$ & $9 / 38$ & $7 / 38$ & $9 / 38$ & $14 / 38$ & $9 / 38$ & $6 / 36$ \\
\hline $7 / 38$ & $10 / 30$ & $10 / 30$ & $8 / 37$ & $12 / 31$ & $10 / 30$ & $12 / 31$ & $14 / 31$ & $10 / 30$ & $7 / 38$ \\
\hline $7 / 38$ & $8 / 37$ & $7 / 38$ & $7 / 38$ & $6 / 36$ & $8 / 37$ & $6 / 36$ & $10 / 36$ & $8 / 37$ & $7 / 38$ \\
\hline $12 / 36$ & $14 / 31$ & $12 / 36$ & $14 / 38$ & $12 / 36$ & $10 / 38$ & $7 / 38$ & $10 / 38$ & $12 / 36$ & $14 / 31$ \\
\hline $14 / 38$ & $10 / 36$ & $14 / 31$ & $10 / 36$ & $14 / 38$ & $10 / 38$ & $7 / 38$ & $10 / 38$ & $14 / 38$ & $10 / 36$ \\
\hline $10 / 38$ & $11 / 30$ & $11 / 30$ & $9 / 37$ & $14 / 31$ & $11 / 30$ & $10 / 30$ & $11 / 30$ & $11 / 30$ & $10 / 38$ \\
\hline $10 / 38$ & $9 / 37$ & $10 / 38$ & $10 / 38$ & $10 / 36$ & $9 / 37$ & $8 / 37$ & $9 / 37$ & $9 / 37$ & $10 / 38$ \\
\hline $73 / 300$ & $80 / 268$ & $80 / 270$ & $73 / 298$ & $81 / 282$ & $72 / 286$ & $63 / 284$ & $90 / 284$ & $77 / 282$ & $76 / 286$ \\
\hline $24 \%$ & $30 \%$ & $29 \%$ & $25 \%$ & $29 \%$ & $25 \%$ & $22 \%$ & $31 \%$ & $27 \%$ & $27 \%$ \\
\hline
\end{tabular}


TABLE I

\begin{tabular}{|c|c|c|c|c|c|c|c|c|}
\hline \multirow{2}{*}{ Effect on } & \multirow{2}{*}{ Patier } & \multirow{2}{*}{ nt } & \multirow{2}{*}{.. } & \multicolumn{2}{|c|}{ Improvement } & \multirow{2}{*}{ Worse } & \multirow{2}{*}{$\begin{array}{l}\text { No } \\
\text { Change }\end{array}$} & \multirow{2}{*}{$\begin{array}{l}\text { No Pain } \\
\text { Initially }\end{array}$} \\
\hline & & & & Partial & Complete & & & \\
\hline \multirow{8}{*}{$\begin{array}{c}\text { Assess- } \\
\text { ment } \\
\text { after } \\
5 \mathrm{~min} .\end{array}$} & \multirow{4}{*}{$\begin{array}{l}\mathbf{A} \\
\mathbf{D} \\
\mathbf{R} \\
\mathbf{E} \\
\mathbf{N} \\
\mathbf{A} \\
\mathbf{L} \\
\mathbf{I} \\
\mathbf{N} \\
\mathbf{E}\end{array}$} & \multirow{2}{*}{ First trial } & Subjective & 1 & 3 & 1 & 31 & 3 \\
\hline & & & Objective & 8 & 1 & 1 & 28 & 1 \\
\hline & & \multirow{2}{*}{ Replication } & Subjective & 2 & 10 & 3 & 16 & 8 \\
\hline & & & Objective & 0 & 6 & 3 & 27 & 3 \\
\hline & \multirow{4}{*}{$\begin{array}{l}\mathbf{C} \\
\mathbf{O} \\
\mathbf{N} \\
\mathbf{T} \\
\mathbf{R} \\
\mathbf{O} \\
\mathbf{L}\end{array} \mid$} & \multirow{2}{*}{ First trial } & Subjective & 2 & 5 & 0 & 31 & 1 \\
\hline & & & Objective & 6 & 1 & 2 & 29 & 1 \\
\hline & & \multirow{2}{*}{ Replication } & Subjective & 1 & 9 & (1)(a) & 20 & 9 \\
\hline & & & Objective & 4 & 4 & 2 & 27 & 2 \\
\hline \multirow{8}{*}{$\begin{array}{l}\text { Assess- } \\
\text { ment } \\
\text { after } \\
30 \mathrm{~min} .\end{array}$} & \multirow{4}{*}{$\begin{array}{l}\text { A } \\
\text { D } \\
\text { R } \\
\text { E } \\
\text { N } \\
\text { A } \\
\text { L } \\
\text { I } \\
\text { N } \\
\text { E }\end{array}$} & \multirow{2}{*}{ First trial } & Subjective & 6 & 6 & (3)(a) & 22 & 3 \\
\hline & & & Objective & 10 & 4 & 2 & 22 & 1 \\
\hline & & \multirow{2}{*}{ Replication } & Subjective & 3 & 11 & 0 & 17 & 8 \\
\hline & & & Objective & 3 & 7 & 1 & 25 & 3 \\
\hline & \multirow{4}{*}{$\begin{array}{l}\text { C } \\
\mathbf{O} \\
\mathbf{N} \\
\mathbf{T} \\
\mathbf{R} \\
\mathbf{O} \\
\mathbf{L}\end{array}$} & \multirow{2}{*}{ First trial } & Subjective & 4 & 6 & 1 & 27 & 1 \\
\hline & & & Objective & 9 & 1 & 3 & 25 & 1 \\
\hline & & \multirow{2}{*}{ Replication } & Subjective & 3 & 8 & $(3)(b)$ & 18 & 9 \\
\hline & & & Objective & 5 & 4 & 1 & 27 & 2 \\
\hline \multirow{2}{*}{ Total } & & Adrenal & . & 33 & $48(81)$ & $14(a)$ & 188 & 30 \\
\hline & & Control & .. & 34 & $38(72)$ & $13(c)$ & 204 & 26 \\
\hline
\end{tabular}

(a) includes one with no pain initially.

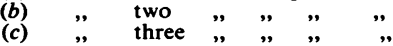

The only certain facts which emerged were these:

(1) Partial improvement occurred more frequently on the first objective assessment (at both 5 and 30 minutes and with both control and adrenaline cream) than on the replication (Table I).

(2) Complete improvement occurred more frequently subjectively than objectively and more often on the replication than on the first assessment (Table I).

(3) The pain had disappeared completely in several patients by the time of the replication (one week), a fact for which due allowance is made. In some, partial disappearance at this time (subjective only) had occurred. 
TABLE III

ANALYSIS OF REPRODUCIBILITY

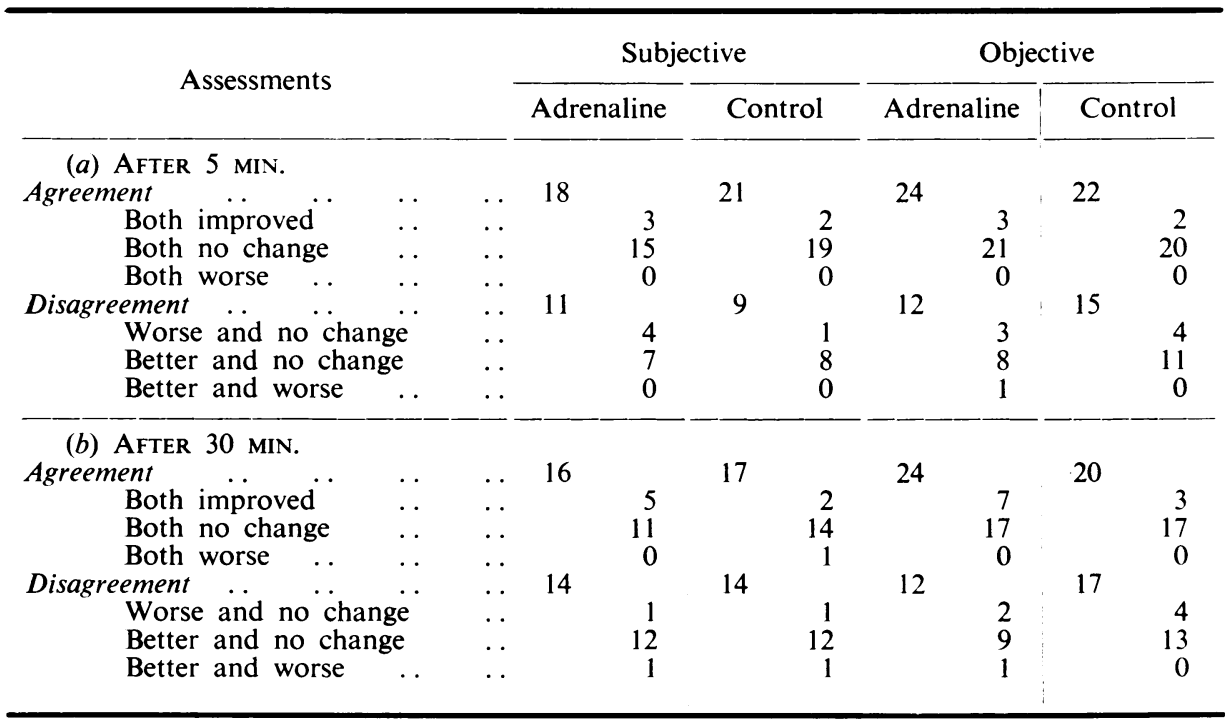

(4) Agreement between the first trial and the replication (Table III) was more common than disagreement, both for subjective and for objective assessments, and especially at 5 minutes ( 85 to 47 ); but this was chiefly accounted for by those cases who showed no change. Disagreement was more common than agreement, if we include in the latter only cases which showed improvement both at the first testing and also at the replication ( 47 to 10 at 5 minutes, and 57 to 18 at 30 minutes).

(5) Some observers consistently scored " improvement ", " no change ", or " worse " more often than the rest. Comparing four centres who analysed five to eight cases each (Table IV), the percentage improvement ranges between $6,17,37$, and 43 , with " worsening" in $12,0,5$, and 4 per cent. respectively. This could be due to pessimistic and sceptical patients in the first centre, and expectant and hopeful ones in the others, which seems more probably due to psychological conditioning in the centre than to natural selection. It is not thought that standards of assessment varied much, since there is in general good agreement between subjective and objective responses.

TABLE IV

\begin{tabular}{|c|c|c|c|c|c|c|}
\hline \multirow[t]{2}{*}{ Centre } & \multirow{2}{*}{$\begin{array}{l}\text { No. of } \\
\text { Cases }\end{array}$} & \multirow{2}{*}{$\begin{array}{c}\text { Improve- } \\
\text { ment }\end{array}$} & \multirow{2}{*}{ Worsening } & \multirow{2}{*}{ Total } & \multicolumn{2}{|c|}{ Per cent. } \\
\hline & & & & & Improved & Worse \\
\hline A & 6 & 32 & 4 & 87 & 37 & $4 \cdot 6$ \\
\hline B & 5 & 12 & 0 & 72 & 17 & 0 \\
\hline D & 6 & 5 & 10 & 86 & $5 \cdot 8$ & $11 \cdot 6$ \\
\hline $\mathrm{H}$ & 8 & 47 & 4 & 110 & 43 & $3 \cdot 6$ \\
\hline
\end{tabular}


(6) Comparing the results for "adrenaline cream" with those of the control cream, no significant difference was found for either the subjective evaluation (additive $\chi^{2}=0.675, n=4, p$ between 0.95 and 0.98 ), the objective evaluation (additive $\chi^{2}=0.690, n=4, p$ between 0.95 and 0.98$)$, or both together $\left(\chi^{2}=1 \cdot 365, n=8\right.$, and $p>0.99$ ). Thus we are unable to demonstrate a significant difference using the above criteria between the proportion improved on adrenaline cream and those improved on the control cream.

(7) The retrospective enquiry about the duration of relief from pain (Table V) showed no significant difference between those treated with control and those treated with adrenaline cream $\left(\chi^{2}=0 \cdot 25\right)$.

TABLE V

DURATION OF RELIEF

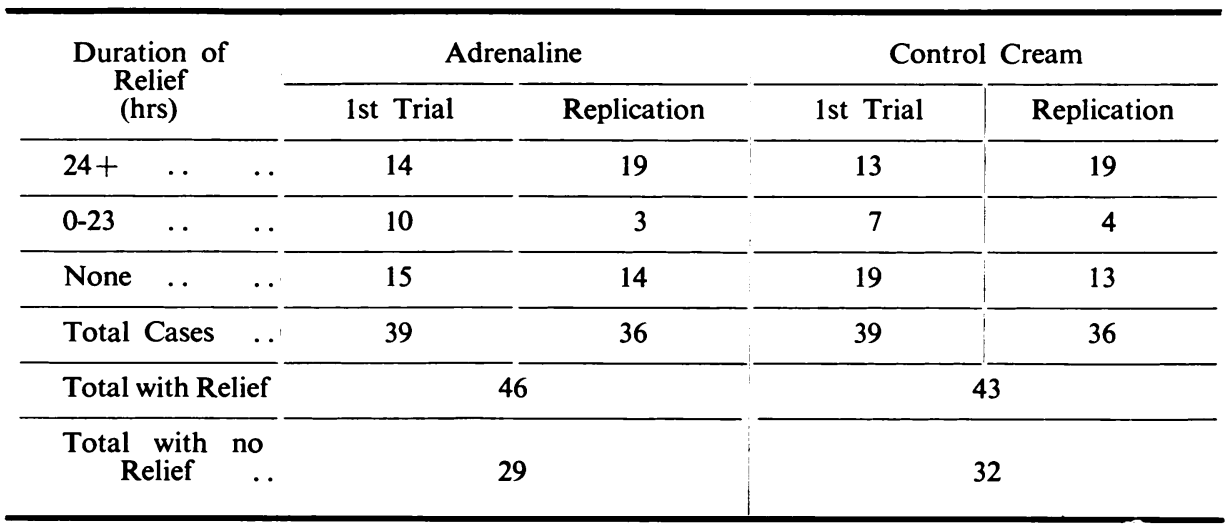

No significant difference is demonstrated. $\left(\chi^{2}=0 \cdot 25.\right)$

It may be alleged that adrenaline is unstable and rapidly disintegrates. No special precautions were taken to prevent this, but it seems likely that a good reproduction of the conditions seen in daily practice was achieved.

\section{Conclusion}

We conclude that there is little difference between the effects of the proprietary preparation costing $3 s$. $9 d$. a tin and a similar unmedicated cream, the basic ingredients of which cost $2 d$. for the same amount, and that what difference we have demonstrated by this method of testing is too small to warrant the assumption of a significant difference between the two products.

\section{Summary}

(1) A trial was planned at the request of the Empire Rheumatism Council to evaluate the therapeutic efficiency of a cream containing adrenaline which was claimed to relieve the pain of "fibrositis" when rubbed into the painful area.

(2) Experiments were carried out at ten rheumatism clinics. A total of 39 patients with pain in two sites were massaged with adrenaline cream at one site, and with a control cream (of similar composition but excluding adrenaline) at the other. A week later the procedure was repeated with the sites reversed. The 
investigators were unaware which cream was which, and the massage was all done by the same person at each centre. The degree of pain was assessed subjectively and objectively, before treatment, and $5 \mathrm{~min}$., $30 \mathrm{~min}$., and one week after treatment.

(3) Improvement, partial or complete, occurred in 29 per cent. of trials with adrenaline cream, and in 25 per cent. of controls.

(4) The difference between the results with adrenaline cream and those with the control cream was too small to be significant; it was concluded, therefore, that there was little difference between the effects of the two creams when tested by this method.

Acknowledgements are due to the staff of the ten centres centres listed above who carried out the investigation and provided the data on which this analysis is based.

\section{E. G. L. BYWATERS, F.R.C.P. Chairman, Research Sub-Committee of the Empire Rheumatism Council}

Howell, T. H. (1950). Lancet, 2, 395.

\section{REFERENCES}

Moss, L. (1949). Med. World, London, 70, 244.

Comparaison de la Valeur Thérapeutique des Frictions avec la " Crème à l'Adrénaline" et des Frictions avec une autre Crème dans des Affections accompagnées de Douleur Profonde

\section{RÉSUMÉ}

(1) A la demande de l'Empire Rheumatism Council des recherches furent entreprises afin de déterminer l'efficacité thérapeutique d'une crème contenant de l'adrénaline qui, appliquée en friction à la surface endolorie, atténuerait-prétendait-on-la douleur de la "fibrosite ".

(2) Des recherches furent effectuées dans dix cliniques rhumatologiques. En tout, 39 malades se plaignant de douleur en deux endroits différents durent frictionnés avec la crème adrénalinée à un endroit, et avec la crème-étalon (de composition similaire, mais sans adrénaline) à l'autre. Une semaine plus tard on répéta le procédé en inversant l'endroit de l'application. Les expérimentateurs ignoraient l'identité précise des crèmes, et dans chaque centre toutes les frictions furent effectuées par la même personne. Le degré de la douleur fut déterminé subjectivement et objectivement avant le traitement, et 5 minutes, 30 minutes, et une semaine après le traitement.

(3) Une amélioration, partielle ou totale, se produisit dans $29 \%$ des applications de la crème adrénalinée et dans $25 \%$ des applications de la crème-étalon.

(4) La différence entre les résultats acquis avec la crème adrénalinée et ceux obtenus avec l'étalon était trop petite pour etre significative. On en conclut, par conséquent, qu'il y avait très peu de différence entre les deux crèmes comparées au moyen de la méthode décrite.

\section{Comparación del Valor Terapéutico de Masaje con " Crema de Adrenalina" y con otra Crema en Afecciones acompañadas de Dolor Profundo \\ Sumario}

(1) A solicitud del Empire Rheumatism Council investigaciones fueron emprendidas para determinar la eficacia terapéutica de una crema conteniendo adrenalina que pretendidamente calmaba el dolor de la "fibrositis" al frotar con ella la zona endolorida.

(2) Investigaciones fueron efectuadas en diez clínicas reumatológicas. En total, 39 enfermos con dolor en dos sitios diferentes fueron friccionados con crema adrenalinada en un sitio, y con una crema de control (de composición similar, pero sin adrenalina) en el otro. Una semana más tarde el procedimiento fué repetido, invirtiendo los sitios de aplicación. Los experimentadores ignoraban la identidad precisa de las cremas, y en cada centro el masaje era practicado por una misma persona. El grado de dolor fué determinado subjetiva y objetivamente antes del tratamiento, y 5 minutos, 30 minutos, así como una semana después del mismo.

(3) Mejoría, parcial o completa, ocurrió en $29 \%$ de los experimentos con crema de adrenalina, y en $25 \%$ de los experimentos de control.

(4) La diferencia entre los resultados obtenidos con crema de adrenalina y con la de control fué demasiado pequeña para ser significante. Se concluye, por lo tanto, que era poca la diferencia entre las dos cremas, cuando comparadas por este método. 